\title{
NIMEDE KIRJUTAMISEST XIX SAJANDI HAUATÄHISTEL JA MEETRIKARAAMATUTES
}

\author{
PILLE ARNEK
}

$\mathrm{M}$ eetrikaraamatud on uurijate huviorbiiti sattunud sageli, kuid vanemad eestikeelsed hauatähiste tekstid on senini teenimatult tähelepanuta jäänud. Kui meetrikaraamatusse tegi sissekanded pastor, siis hauakirja kirjutajaks oli üldjuhul risti valmistanud sepp või kiviraidur. Puuristile võis talupoeg ka ise teksti kirjutada, kuid sellised ristid ei ole paraku säilinud. Nii tekib võrdlusvõimalus pastorite (aga ka teiste õppinud kirjameeste) ja meistrite ning talupoegade kirjutustavade vahel.

Perekonnanimede paneku ajal oli võimalik talupoegadel ise nimed valida, erinevatel põhjustel võis seda teha ka mõisnik. Mõisnike pandud nimed olid tihti saksakeelsed või moonutatud eesti nimed. Seevastu pastorite mõju oli pigem vastupidine. Kirikuraamatutesse on sageli nimi kirjutatud eestipärasemal kujul kui hauatähisel, kuhu nimekandja lähedased selle oma soovi järgi on kirjutanud. Nimede ebajärjekindla kirjutusviisi põhjuseid on mitmeid ning sageli esinevad need kombineeritult: mõisnike ja pastorite mõju, kadakasakslus, eesti keele mõju (sh kuulmise järgi kirjutatud nimed, murdemõjud, „kirjavead" saksapärastes nimedes jms), üleminek uuele kirjaviisile jne.

Nagu öeldud, esineb nimekirjutuses suuri varieeruvusi. Põhjuste täpsemaks väljaselgitamiseks analüüsisin 18 kalmistu hauakirju (vt joonist 1) ligikaudu 500 nimega (arhiivides olevad andmed ning 2010.-2012. aastal kalmistutelt üleskirjutatud tekstid). Kõik hauakirjad pärinevad XIX sajandist materjali ajaline piir on seatud surma-aasta järgi. Võrdlesin nimede kirjutust hauatähistel sünni- ning surmameetrikaraamatute andmetega. Meetrikaraamatute andmed pärinevad Rahvusarhiivi ja Tallinna Linnaarhiivi digiteeritud arhiiviallikatest (SAAGA). Meetrikaraamatute sissekanded on teinud erineva päritolu ja taustaga pastorid, nende kohta leiab informatsiooni Liivi Aarma raamatutest „Põhja-Eesti kirikud, kogudused ja vaimulikud. Matriklid 15251885” (2005) ning „Põhja-Eesti vaimulike lühielulood. 1525-1885” (2007).

Huvitavat informatsiooni annavad nimed, mis korduvad erinevatel hauatähistel. Surmameetrikatest on andmed kõigi 18 kalmistu kohta (kokku 461 isikunime), sünnimeetrikatest otsisin andmeid viie kalmistu kohta ning kokku leidsin 20 hauakirjadega kattuvat nime. Sünnimeetrikatest nimede otsimist raskendavad mitmed asjaolud: naiste perekonnanimi abielludes muutub, inimesed on kolinud teise kihelkonda, sissekanded on kohati väga raskesti loetavad jms. Lisaks oleks võimalik kasutada abiellunute nimistuid, hingeloenduste andmeid jms dokumente.

Nimede kirjapilt hauatähistel erineb olulisel määral kirikuraamatute (surmameetrikate) sissekannetest. Sagedasemad erinevused tähisel ja kirikuraamatus: 


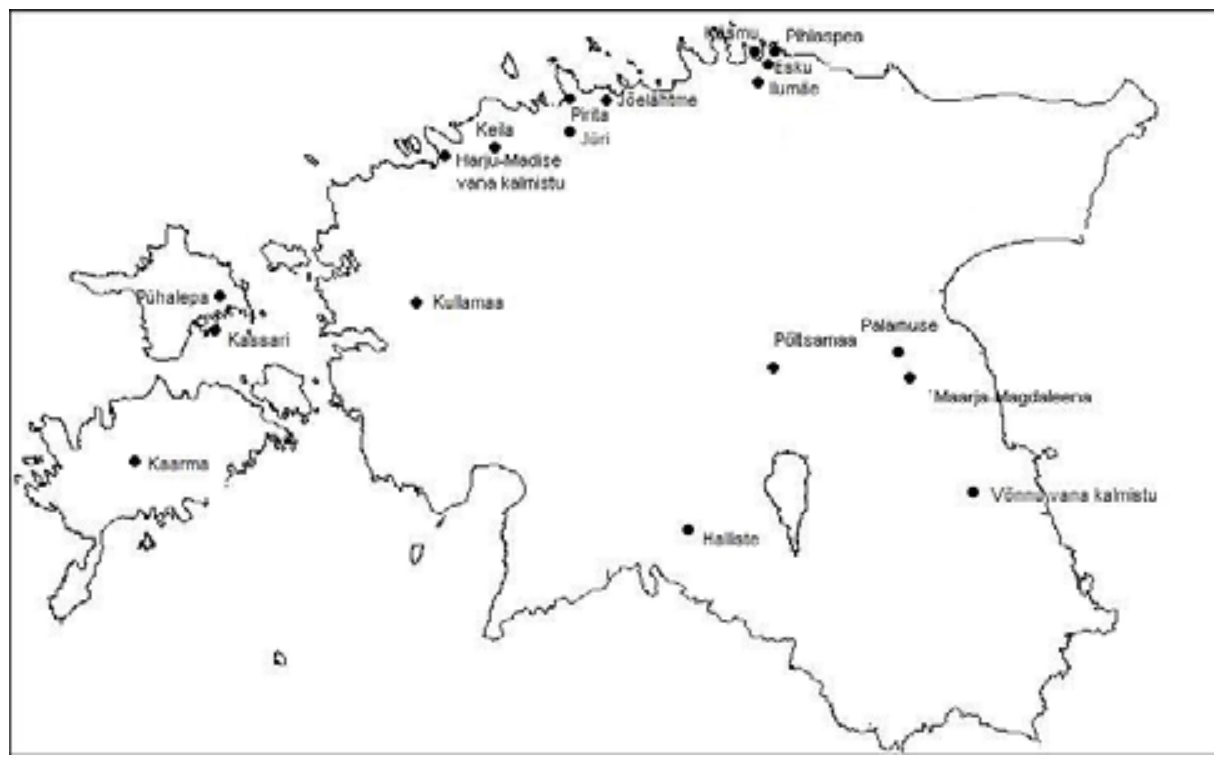

J o o n i s 1. Analüüsitud kalmistud.

1. Topelttähe ärajätmine või lisamine: Rodemann - Rodeman.

2. Väiksemad täheerinevused: Lena-Leenu / Jakub-Jakob / HindrekHendrik.

3. Muutused silbistruktuuris: Prosahallik-Prosalik.

4. Mõnikord on lisatud või ära jäetud mõni lisanimi.

5. Saksa- vs. eestipärane: Rosenberg - Rosimäe / Neitor-Neudorff / Pärnart-Bernhard / Ants-Hans / Juhan-Johhanes.

6. Erinevusi tekitab uue kirjaviisi levik: Kröt-Krööt / Juhhan - Juhan / Kaasik-Kasik.

7. Erinev murdetaust, võimalik vähene kirjakeeleoskus (?) ja muud ebaselged muutused: Rutolw-Rudolf / Pärnama Toma-Peerneme Tomes. Viimases näites on võimalik rannarootsi murde mõju.

8. Harvem esineb tähtede ümberpaigutumist: Fitelnberg - Filenberg.

Häälduse järgi kirja pandud variandid on tegelikult selgelt äratuntavad ühe nimena, nii et ühtse kirjapildi järgi ei olegi väga suurt vajadust. Varieeruvusi esines tähistel siiski rohkem kui kirikuraamatus.

XIX sajandil puudus järjepidevus nimekirjutuses ka haritumas pruugis, täpsele kirjutusele ei pööratud tähelepanu. Sellest hoolimata on võimalik leida erinevaid tegureid, mis sellise kireva olukorra tekitasid: 1) mõisnike mõju; 2) saksa pastorite mõju - kas on eesti või saksa emakeelega pastor, pastori meelsus; 3) kadakasakslus; 4) nimede eestindamine ja eesti keele mõju (nt rõhu nihkumine esimesele silbile; ortograafia areng); 5) kirjapanekud kuulmise järgi, kirjavead; 6) murdemõju; 7) vana ja uus kirjaviis; 8) nimede lühenemine kasutuses; 9) ristinimi vs. hüüdnimi (kuidas inimest tegelikult elu jooksul kutsuti); 10) vanade lisanimede kasutamine ka pärast perekonnanimede panekut; 11) juhuslikud muutused. 
See loetelu ei ole täielik ning alati ei ole mõjutegureid võimalik eristada, seda enam, et sageli ongi mitu mõjutegurit koos.

Hauatähisele kirjutas teksti kiviraidur või sepp, kes tähise valmistas. Paljudel XIX sajandi teise poole ristidel (nii puust ristidel, artelli sepistel kui ka valuristidel) on tekst väikesel vaskplaadil. Sellistele plaatidele kirjutas teksti graveerija. Puust risti võisid taluperemehed oma pereliikmetele ise valmistada. Sel juhul oli tekstikirjutajaks peremees. Tuli ette sedagi, et juba eluajal endale rist valmis tehti (Korb 2007: 165), kuid tekst kirjutati ilmselt alles siis, kui rist kasutusse läks. Seega on hauakirjade kirjutajateks erineva taustaga inimesed, kuid kindlasti ei ole need kirikuõpetajad ega kirjamehed. Kõige lähemal kirjameestele olid ehk graveerijad, kuid nendegi kirjutistes võib leida väga suuri erinevusi ja isegi otseseid kirjavigu.

\section{Mõisnike osa}

Perekonnanimede panek eestlastele toimub Liivimaa kubermangus 18231826 ning Eestimaa kubermangus 1835 (Tiik 1987: 84-85). Artiklikogumikus „Eestlasele eesti nimi” (1921) kirjutab Matthias Johann Eisen, et perekonnanimede panek oli mõisa kohustus ning kirikuõpetajatel oli siin vähe mõju. Kihelkonnakohus pidi nimestikke revideerima, kuid nende tööst on vähe jälgi (Tiik 1987: 85). Sageli oli just pastori roll oluline järgnevas nimede korrastamise töös, sest tema teadis paremini talupoegade sugulussuhteid (Must 2000: 56). Seega perekonnanimesid panid ning kandsid hingeraamatusse küll mõisakirjutajad, kuid korrastada aitasid neid nimekirju mõnel pool ka pastorid. Kord pandud perekonnanime oli võimalik muuta vaid kohtu loal ning teatava tasu eest. Täpsem nimemuutmise reeglistik pandi paika siiski alles 1880 . aastatel (Must 2000). Seetõttu võisid nimed vallaraamatutes ja kirikuraamatutes erineda. Sellist olukorda kirjeldab M. J. Eisen (1921): nimesaajad on kiriku juures üles andnud teise nime, kui neil mõisas kirja pandi, ning see kirikukirjade nimi jäigi kirikukirjadesse edasi (olgu laulatus, ristimine või matus). Mõisnike mõju piirdub perekonnanimede panekuga, hiljem neil enam isikunimedele mõju ei ole.

\section{Pastorite osa}

Kirikuraamatutesse (sünni- ja surmameetrikad) tegi sissekanded pastor või tema abiline (diakon, pastor-adjunkt, abipastor vms). Väiksemates kogudustes abilisi ei olnud ning seal jäi kogu töö tõenäoliselt pastori kanda. Päris kindlaid andmeid sissekannete tegijate kohta ei ole, kuigi käekirju tuvastades oleks võimalik pisut selgust tuua.

Pastoritel oli XIX sajandil eesnimede panekul suur mõju. Laps sai endale eesnime ristsetel ning pastor kandis nime sünnimeetrikaraamatusse, kasutades just sellist kirjapilti, mida ta kõige õigemaks pidas. Siin sai määravaks kirikuõpetaja enda päritolu ja taust. Paavo Annuse andmetel (Annus 1996: 109) on näiteks Järva-, Lääne- ja Virumaal kuni 1850. aastateni kõik pastorid saksa päritolu, seejärel hakkab kasvama eesti päritolu pastorite osakaal ning viimased saavutavad ülekaalu 1890. aastatel. Tuleb arvestada, et ka mitte- 
eestlastest vaimulike seas oli inimesi, kes huvitusid eesti keelest rohkem, kui ametikoht nõudis. Võrreldes hauakirju meetrikaraamatutega, tuleb ette juhtumeid, kus just pastor on eestindamise pooldaja ning talupoeg eelistab saksapärast nime. Kadakasaksluse mõjudest tuleb juttu hiljem.

Nagu öeldud, kord pandud perekonnanime enam muuta ei võinud. Üks 1860. aastal välja antud kooliraamat annab järgmise juhise: „Kui üks mees omma ninme nenda kirjotab: „Peter Raudsep”, teine nenda "Peter Rautsep”, siis tunneb sest weikessest wahhest, et teine teisest sugguarrust on. Prinimme kirjotamisse jures on agga se seädus, et sedda kunnagi ei mudeta, waid nenda kui mees omma prinimme nüüd kirjotab, nendasammoti ka saa aasta pärrast temma lapsed ja laste lapsed" (Koli-ramat 1860: 16). Sellistest korraldustest ei peetud kuigi täpselt kinni. Kord sünnimeetrikasse kantud nimi võib hauatähisel olla teisel kujul ning surmameetrikas veel kolmandas variandis. Enamasti on tegu väiksemate tähemuutustega, nimevahetust või nime tõlkimist tuleb harvem ette.

Ühel Jõelähtme kalmistu raudristil on trükitähtedes tekst „Siin hingab Jummala rahho sees, Heindrich Mikkom. Sund. 22 Aug. 1795 surn. 18 Juli. 1843”. Sünnimeetrikas on sama nimi kujul Hinrik Koilast ning surmameetrikas Hindrek Mikkom. Kõik kolm eesnime kirjapilti erinevad. Sünnimeetrika sissekanne on tehtud enne üldist perekonnanimede panekut ja seetõttu on täiendiks kohanimi. Sel ajal oli Jõelähtme pastor Hannoveris sündinud Georg Friedrich Schüdlöffel (Aarma 2005: 69; 2007: 247). Saksa päritolu Schüdlöffel on samas sünnimeetrikas tihti kasutanud just sellist nimekuju - Hinrik. Mis tema eelistuse põhjustas, ei ole teada. 1829.-1859. aastani oli Jõelähtme pastoriks tema poeg Gustav Heinrich Schüdlöffel, kes kogus eestlaste folkloori, oli eestikeelne kalendrikirjanik ning kasutas juba 1844. aastal esimest korda oma raamatus Ahrensi eesti keelele sobivat soomepärast ortograafiat (Aarma 2007: 247). Ilmselt on surmameetrika sissekanne tema tehtud ning seetõttu on mõistetav eestipärase kirjapildi eelistus. Perekonnanime siin muudetud ei ole.

\section{Sissekanded sünni- ja surmameetrikates vs. hauakirjad}

Võrreldes samu isikunimesid sünni- ja surmameetrikates, leidub väiksemaid tähemuutusi, kuid suuri erinevusi üldjuhul nimedes ei ole. Seega kirjutasid pastorid suurema tõenäosusega nimesid ühtmoodi, ilmselt ei kontrollinud nad siiski varasematest meetrikaraamatutest sama isikunime kirjapilti, vaid kirjutasid harjumuspärasel moel. Sellest võisid tulla ka väiksemad täheerinevused meetrikaraamatutes.

Hauakirjade ja meetrikaraamatute vahel on erinevusi rohkem. Hauakiri ei ole dokument, seega seatud nõuded perekonnanime muutmise kohta otseselt hauakirju ei puuduta. Nii oli hauakirja kirjutajal rohkem vabadust oma eelistusi rakendada. Kui aga inimene elu jooksul kasutas üht kirjutusviisi, siis ei ole põhjust seda alles hauakirjal muuta. Nii võib oletada, et tähisel on just see nimi, mida inimene tegelikkuses ka kasutas. Eesnimesid toonased seadused ei puudutanud, ilmselt seetõttu on rohkem muutusi just eesnimedes. 


\section{Kadakasakslus}

Perekonnanimede panekul mõisates said paljud eesti talupojad endale saksapärased nimed. Kuid ka hiljem on eestikeelseid nimesid nii sakslaste kui ka eestlaste omal tahtel saksastatud (Eisen 1921: 15). XIX sajandi teise poole nimemuutmistes domineeris just eestikeelsete nimede saksastamine ning kõige enam puudutas see linnadesse jõudnud eestlasi (Must 2000). Mida kõrgemale ametikohale jõuti, seda kasulikum oli omada saksa nime. Eiseni arvates oli suur mõju saksa koolil, sest eesti perenimed koolis saksastati. Mitte ainult nimesid ei kirjutatud saksapäraselt, vaid kohati on kogu hauakiri saksa keeles hoolimata asjaolust, et maetu oli eestlane. Leo Tiik (1969: 534) möönab samuti, et sisuliselt kehtis tsaariaja lõpuni rahvastiku jaotus seisuse järgi ning eestikeelne nimi reetis nimekandja kuuluvuse talupojaseisusesse, samal ajal kui linnakodanikule või kaupmehele ei sobinudki eesti nimi.

Näiteid, kus pastor on kasutanud eestipärast nimekuju ning hauatähisel on saksapärane, tuleb ette mitmel pool. See ei ole tingimata näide pastori eestimeelsusest, vaid kui kord sai sünnimeetrikasse kirja eestipärane nimi, siis on pastor seda kasutanud ka hiljem. Inimene ise on aga eelistanud saksapärast varianti. Ka on võimalik, et pastor ei tahtnud eestlasele sihilikult saksapärast nime anda, pidades seda ebasobivaks. Nagu sünni- ja surmameetrikate ning hauakirjal olevate nimede võrdlus näitas, on erinevused väiksemad kirikuraamatutes (sünni- ja surmameetrikaid omavahel võrreldes) ning suuremad hauakirjade ja surmameetrikate vahel. Osalt võis seda põhjustada talupoegade vähene kirjaoskus, kuid kui hauatähisel on eelistatud selgelt saksapärast nime, siis seda tagasihoidliku kirjaoskusega põhjendada ei saa.

Kõigil analüüsitud kalmistuil (v.a Pirita kloostrikalmistul) on ligikaudu kaks korda sagedasemad juhtumid, kus hauatähisel on nimi saksapärasemalt kirja pandud kui surmameetrikas. Sellist kirjapildi muutust esines 41 korral 314-st ehk $13 \%$-l analüüsitud nimedest. Vastupidist olukorda, kus nimi oleks tähisel eestipärasemalt kirjas kui surmameetrikas, esines 16 korral ehk $5 \%$-l üleskirjutustest. See tendents sagenes märgatavalt alates 1870. aastatest, kuid ei saavutanud ülekaalu. Järelikult oli inimeste soov nime saksapäraseks muuta siiski valdavam kui nimede eestindamine (joonis 2). Erandiks on analüüsitud materjali hulgas Pirita kloostrikalmistu, kus mõne protsendi

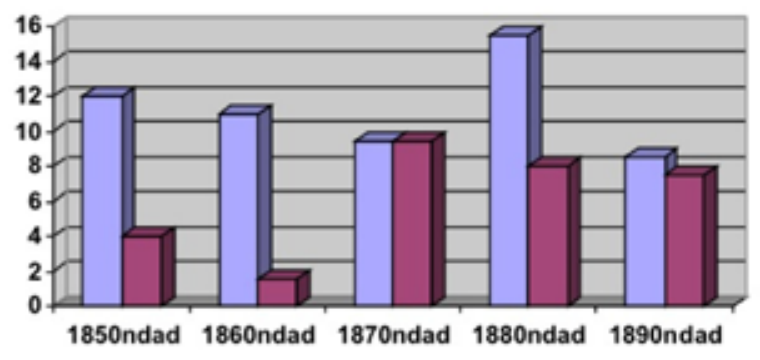

$\square$ Ristil saks apărane nimekuju

a Ristil eestipärane nimekuju

J o o n is 2. Inimeste eelistus kasutada hauatähistel saksapärasemat või eestipärasemat nimekuju võrreldes surmameetrikate sissekannetega (protsentides). 
võrra sagedamini esines ristil eestipärasem nimekuju (10 \%) võrreldes surmameetrikaga ning vastupidist olukorda esines 7,5\%. See kalmistu oli XIX sajandil Tallinna Pühavaimu ja alates 1868. aastast Tallinna Jaani koguduse hallata. Maeti sinna aga Viimsi poolsaare ja Nehatu küla inimesi (mitte linnaelanikke). Suuremates linnakogudustes püsisid kauem saksa päritolu pastorid, samas on suurtes kogudustes raskem selgitada, kes tegid sissekandeid meetrikaraamatutesse.

Massiliseks ei saanud nimede muutmine XIX sajandil tasu tõttu, mis selle eest välja tuli käia, kuid näiteid saksapärastest nimekujudest leiab kõigil kalmistutel: kirikuraamatus on nimi Katarine, ristil aga Catharine või kirikuraamatus Jallakas, ristil Jalack. Pirita kloostrikalmistule on 1875. aastal pandud rist nimega Marie Rosenberg, kirikuraamatus on sama isik nimega Maria Rosimäe. Siin on nimi ristil tõlgitud saksa keelde, kuid ilmselt ei ole seda ametlikult muudetud. Esineb ebaselgeid muutusi: 1846. aasta Jõelähtme kirikuraamatus Küspärk, ristil Kreisberg. Võimalik, et mõisniku juures pandi talupojale saksa nimi, kuid hiljem kirikuraamatusse sissekannet tehes ei teadnud ta nime kirjapilti või ei osanud seda õigesti hääldada. Pastoriks oli Jõelähtmel sel ajal uue kirjaviisi varane rakendaja G. H. Schüdlöffel, võib-olla tuleks põhjuseid otsida tema innukusest. Kuigi berg-lõpu muutumist perk-iks või pärk-iks tuleb ette mitmel pool.

Kui kirikuraamatus on endiselt eestipärane nimi, siis ei ole nime ametlikult muudetud. Seega eelnev analüüs käib eelkõige mitteametlike nimemuutuste kohta.

\section{Eesti keele mõju}

Koos kadakasaksastumisega toimus vastupidine protsess. XIX sajandi teisel poolel said hoogu rahvusliku ärkamisaja ideed. Suurt tähelepanu pöörati eesti keele arendamisele. Kuivõrd jõudis see talupoegade ja muu lihtrahvani? Väga selgeid viiteid hauakirjadelt ei leia. On küllaldaselt nimesid, mis on tähisele kirjutatud eesti keelele omasemalt kui kirikuraamatus. Nende muutuste taga võib olla soov kasutada eestipärasemat nime, kuid võimalikud on ka ebateadlikud teisendused: nime kirjutati nii, nagu hääldades loomulikum tundus. Kuna keelereeglid ei olnud toona selgelt paigas, siis kindlaid järeldusi teha ei saa. Nagu juba öeldud, esineb nimede eestindamist siiski vähem kui saksastamist.

Otsest tõlget eesti keelde esineb ühel korral: kirikuraamatus Wolf (sulgudes on lisatud Hunt), hauatähisel seisab Hunt. Sagedamini esineb väiksemaid tähe- ja häälikumuutusi: hauatähisel Juhhan, Eliisabet, Klarissa, surmameetrikas Johannes, Elisabeth, Clarissa. Mõnel juhul on saksa nimi saanud eestikeelse kõla ja kirjapildi: ristil Pärnad / Pärnat, Ants, Luustbärg, kirikuraamatus Bernhard, Hans, Lustberk. Ette tuleb ka veidramaid nimemoonutusi, kus häälduspäraselt kirjutamine või eestipäraseks muutmine on ebaõnnestunud: ristil Rutolw, Roosenpärk, Limbagh, kirikuraamatus Rudolf, Rosenberg, Limbach. Üks segadust külvanud nimi esineb variantides Öunamann, Öunmann, Aunmann ning mõne nime puhul võib vaid oletada, missugune võis olla nime algvariant hingeraamatus: Koukberks - Kaukperk.

Sagedasemad saksa ja eesti keele iseärasustest tulenevad erinevused: 


\section{Kanep; \\ 1. $k, p, t$ nime alguses: Gustaw - Kustaw, Broosalik - Prosalik, Ganep -}

2. rõhu nihkumine esimesele silbile: Timann-Tiiman;

3. võõrtähed: Carl-Karl, Rosenhoff-Rosenkow, Bachholtz-Bahholts;

4. võõrapärased tähekombinatsioonid: Falck - Falk, Mickel - Mihkel, Hirschfeld - Hirsfeld, Kusick - Kusik;

5. võõrliite lisamine või ärajätmine (seda võib põhjustada ka nimede lühenemine kasutuses): Tamberg - Tam;

6. väiksemad täheerinevused: Juhan - Johan;

7. eesti keele häälduse järgi üleskirjutatud saksa nimed: Muhlbach-Mühlbahk, Neufeld - Neiwelt; vastupidist kohtab harvem: Jallakas - Jalack.

Nimede valiku vabaduses olid teatud kitsendused: valitsuse korraldusel pidid perekonnanimede paneku aegu kirikuvöörmündrid valvama, et rahvas ei võtaks rumalaid, teotavaid ega mõisavalitsejate nimesid (Saareste 1935: 141). Kirjutusviiside kohta mingeid reegleid ei seatud. O. W. Masing püüdis anda küll omapoolseid soovitusi, kuid teda võeti vähe kuulda. Eespool mainitud kooliõpik annab 1860. aastatel järgmise juhise: „Prinimme kirjotamisega on teine luggu, kui mu sannade kirjotamisega. Mönnel prinimmel pannakse üks täht rohkem ehk wähhem, kui muido tarwis olleks. Peälegi prugitakse nende jures ka wahhest Saksakele tähti, nenda et „öigekirjotamisse öppetus” ei wöi juhhatajaks olla, mil wisil prinimmesid kirjotakse. Kui prinimmi juhtub meile ette, mis meile alles teädmata, siis peame teise käest kulama, kuida sedda öiete kirjotaks" (Koli-ramat 1860: 16). Segakeelsed nimed ei ole siin kuidagi taunitud, tuleb kirjutada nii, nagu nimekandja ütleb, ning õigekirjaõpetuse võib justkui päris kõrvale jätta.

\section{Nimede lühenemine ja hüüdnimed}

Laennimede lühenemist ei saa alati lugeda nime muutmiseks. Eesnimede lühikujud (juhul kui meetrikaraamatutes on nimi välja kirjutatud) on pigem hüüdnimed, millega inimest eluajal kutsuti. Ametlikus asjaajamises, kui seda tarvis oli, võis isik kasutada pikemat nimekuju.

Eesnimede lühenemist tuleb sagedamini ette kui perekonnanimede lühenemist. Tihti on kirikuraamatusse kantud algupärane võõrnimi (nt Marie, Juliane, Johannes, Hendrik), kuid inimest kutsutakse lühenenud nimekujuga (Mari, Juuli, Juhan, Hen) ning ka hauatähisele kirjutatakse lühem variant. On ka juhtumeid, kus meetrikaraamatutesse on kantud mitu eesnime, kuid hauatähisel on alles jäänud vaid üks, nt kirikuraamatus Adele Juliane või Aleksander Eduard, tähisel Adele ja Aleksander. Ühel juhul on jäetud ära üks eesnimi ning teist lühendatud ning seda just kirikuraamatus: tähisel Wilhelmine Cristine, kirikuraamatus Mina. Lühenenud nimekujud on kasutusel ka n-ö päris eesnimedena, st kirikuraamatusse kantud juba sellisel kujul: Liso, Lena, Mart. Sellised nimed on väga levinud kogu XIX sajandi vältel.

Perekonnanimede lühenemist tuleb ette mõnevõrra harvem. Nimede lühenemise jälgimiseks ei piisa alati hauakirja ja surmameetrika võrdlusest, sest see on sageli pikem protsess ja toimub mitme põlvkonna jooksul. Kuna XIX sajandil olid inimesed üsna paiksed, siis esineb samu perekonnanimesid 
ühel ja samal kalmistul korduvalt pikema perioodi vältel. See annab võimaluse jälgida ka aeganõudvamaid nimemuutusi. Mõnikord on ära jäetud üksikud tähed, teinekord terve silp sõna keskelt või lõpust. Väiksemad lühenemised võivad aset leida ühe isiku nimes tema elu jooksul, suuremad muutused võtavad kauem aega. Nimest võib kaduda:

1. üks häälik kaashäälikuühendist: Kimberg - Kimber, Kuuskman - Kuusmann, Kaarmann-Kamann;

2. täishäälik, mis põhjustab silpide arvu kahanemise: Meerikülla-Meerküll, Thomason - Thomson, Lilienblum - Lillenblum;

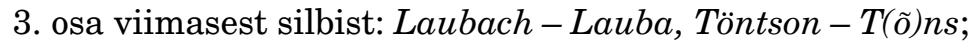

4. võõrliide: Malmus - Malm;

On ka ulatuslikumaid kontraktsioone: Kä̈waots - Kaewal(ts), UndiaugoUndago, Prosahallik-Prosalik.

Perekonnanimi Kaewats on antud Kaevatsi laiul elanud inimestele. Samal laiul on vanadel kaartidel mitu ots-lõpulist kohanime (väiksemad merre ulatuvad maanukid). Mõnest sarnasest kohanimest võib pärineda ka Kaävaots, mis hiljem sai lühema kuju.

Perekonnanimi Proshallik esines korduvalt Pirita kloostrikalmistul erikujudes (Prosahallik, Proosalleik, Proshalik, Prosallik, Broosalik, Prosalik). Läheduses asus Proosa allikas, võib oletada, et perekonnanimi on saadud kohanimest. Nime lühenemine on siin üsna hästi jälgitav.

\section{Üleminek uuele kirjaviisile}

Üheks kõige sagedasemaks nimede kirjapildi muutumise põhjuseks on üleminek uuele kirjaviisile. See lähtus 1843. aastal ilmunud Eduard Ahrensi grammatikast „Grammatik der Ehstnischen Sprache Revalschen Dialektes” (täiendatud trükk 1853). Üleminek uuele kirjaviisile toimus valdavalt siiski alles 1860.-1870. aastatel. Päris lõpule jõuab kahe kirjaviisi vaheline võitlus 1889. aastal piibli ilmumisega uues kirjaviisis (Kask 1958). Mõned nimed on aga tänapäevani säilitanud vana kuju (Leppik, Tõnno, Eva). Varasematel kümnenditel (1840.-1850. aastail) on muutusi raskem jälgida, sest kohati on uue kirjaviisiga sarnane kirjapilt juhuslik, mitte kirjutaja teadlik valik. Ka on neist kümnenditest vähem näiteid ja seetõttu ei ole statistilised andmed usaldusväärsed.

Kiiremini toimus üleminek ilmalikus kirjanduses ja kooliraamatutes, kirikukirjanduses domineeris vana kirjaviis kauem (Kask 1958). Pastorite hulgas oli aga mitmeid eesti keele huvilisi ja neidki, kes keeleuuendustele avatud olid. Teistest kogudustest eristub Jõelähtme, kus juba 1840. aastatel on osa nimesid uues kirjaviisis. Toonasest Jõelähtme koguduse pastorist G. H. Schüdlöffelist on juba korduvalt juttu olnud. Ta kasutas 1844. aastal oma eestikeelses raamatus „Toomas Westen, Lapo rahwa uso ärataja” esimest korda Ahrensi ortograafiat (Aarma 2007: 247). Tema vaated kajastuvad samal kümnendil ka surmameetrika sissekannetes (eesnimed Jüri, Liisu, Leena). Kadrina koguduses töötas aastatel 1800-1843 pastor A. F. J. Knüpffer, kes samuti soovitas eesti keele grammatika aluseks võtta soome grammatika (Aarma 2007: 149-150). Nii võib otsida seoseid teistegi pastorite ja vastavate kirikuraama- 
tute vahel. On ka vastupidiseid näiteid, kus pastor on jäänud truuks vanale kirjaviisile. Nii on Harju-Madisel meetrikaraamatute sissekannetes eelistatud vana kirjaviisi veel 1870. aastatel, kuigi hauatähiste meistrid kasutasid sagedamini juba uut kirjaviisi. Pastoriks oli seal saksa päritolu N. F. H. Spinder (Aarma 2007: 254-255).

Kui uus kirjaviis laiemalt levima hakkas, siis olid just hauatähiste meistrid mõnevõrra kiiremad uusi reegleid omaks võtma (joonis 3).
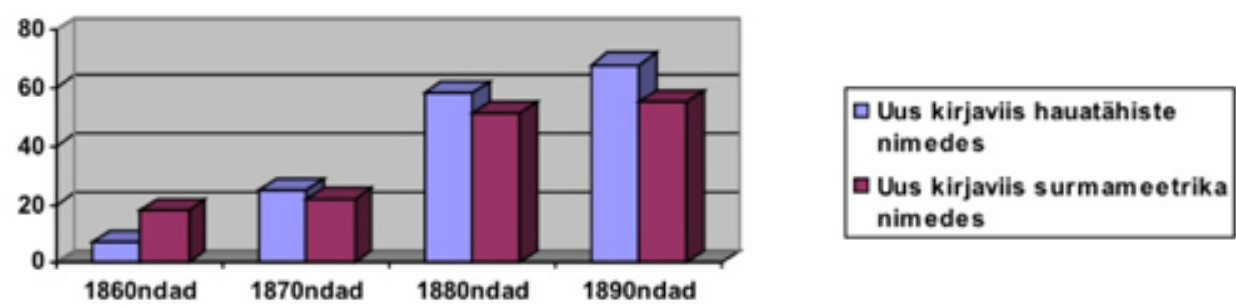

J o o n is 3. Uues kirjaviisis kirjutatud nimede osakaal protsentides (kõik kalmistud).

Nimed ja piiblisalmid püsivad kauem vanas kirjaviisis kui ülejäänud hauatähise tekst (Arnek 2011). Domineerivaks saab uus kirjaviis nii kirikuraamatutes kui ka hauatähistel olevates nimedes 1880. aastatel. Lihtsam on jälgida eesnimede uude kirjaviisi ümberseadmist, perekonnanimede puhul ei ole tihti teada, kuidas nimekandja seda hääldada võis (eriti saksapäraseid nimesid). Perekonnanimede muutmine oli seadusega rohkem reguleeritud ja muutusi võidi ka seetõttu vähem teha. Esineb juhtumeid, kus eesnimi on uues, perenimi endiselt vanas kirjaviisis, nt Juhan Leppik. Segavorme esineb aeg-ajalt mitmetel kalmistutel ja kirikuraamatutes, kuigi mitte palju.

\section{Vanade lisanimede kasutamine}

XVII-XVIII sajandil koosnes talupoegade nimi lisanimest ja selle järele kirjutatud ristinimest, lisanimi omakorda võis kujuneda talunimest, elukutsenimetusest, hüüdnimest või isanimest (Must 2000: 41). Lisanimed olid üsna muutlikud, välja arvatud juhtudel, kui elukoht või amet pärandati põlvest põlve (Alender jt 2003: 11). Lisanimesid kasutati kuni üldise perekonnanimede panekuni, kuid ka pärast seda. Nende kasutus vähenes aja jooksul, kuid ei ole suulises traditsioonis päriselt kadunud tänapäevani.

Ühel 1829. aastast pärineva Pihlaspea kalmistu ristil seisab Kolime Mari, surmameetrikas on sissekanne Kolimaelt Jani $t$ Marri. Hauatähistel esineb selliseid vana kombe kohaseid nimesid kauem. Palju on hauatähiseid 1850.1870. aastatest, kus on kirjas nii vana lisanimi kui ka uus perekonnanimi (Hallistes: Köstre Jaan Kuk, Kalbaküla Mari Schütz; Kullamaal: Käkki Juhhan Tasmuth, Eiasto Karl Sobel; Ilumäel: Allika Ans Muidig; Harju-Madisel: Wassalemmast Pärnama Toma naene Katrina Lillenblum, Wasalemma Männiko Körtso Maddise Poeg Peter Treimann). Silma jäävad hauakirjad, kus li- 
sanimest on saanud inimese perekonnanimi, kuid tähisele on kirja pandud mõlemad (Timmerma Kristjan Timmermann; MerrKülla Michel Meerküll). Kirikuraamatutes hakati enamasti kohe pärast perekonnanimede panekut kasutama uusi nimesid. Üksikuid erandeid tuleb ette ka siin. Pühalepal on 1837. aasta kirikuraamatus kirjas nimi Aida Peter, sama tekst on ka hauatähisel, kuigi selleks ajaks peaks kõigil juba perekonnanimi olema. Harju-Madise meetrikaraamatusse on 1847. aastal kantud nimi Kubja Mati, kusjuures hauatähisel seisab Kubja Mats Niman. Tegemist on pigem üksikute eranditega, kui välja arvata Keila kirikuraamatud. Seal on veel 1870. aastatel kirikuraamatusse kantud vanu lisanimesid, kusjuures perekonnanimi on mitmel korral sisse kandmata jäänud, nt tähisel Halli Kotti Körtsmik Hans Dunkel, Loo Jaak Petermann, kirikuraamatus: Allikoti Hans, Loo Jaak. Sajandi lõpus lisanimesid kirikuraamatutes ega hauatähistel enam ei kohta.

Toonane kirjutustava oli väga varieeruv ning selline mitmekesisus ei olnud midagi ebaharilikku ka haritud kirjameeste hulgas, mis tundub tänapäeval võõrastav. Siiski on võimalik leida erinevaid asjaolusid, mis sellist variatiivsust põhjustasid. Lisaks kirjeldatud nimede muutmise/muutumise põhjustele võiks edaspidi lähemalt analüüsida ka murdetaustu ning rohkem tähelepanu pöörata piirkondlikele mõjudele.

\section{Kirjandus}

A a r m a, Liivi 2005. Põhja-Eesti kirikud, kogudused ja vaimulikud. Matriklid 1525-1885. Tallinn: Aarma Maja.

A a r m a, Liivi 2007. Põhja-Eesti vaimulike lühielulood 1525-1885. Tallinn: G. ja T. Aarma Maja OÜ.

Alender jt 2003 = A l e n d e r, Eve, H e n n o, Kairit, H u s s a r, Annika, P ä 1l, Peeter, S a a r, Evar, Nimekorralduse analüüs. Tallinn: Eesti Keele Sihtasutus.

Annus, Paavo 1996. Luterliku kiriku vaimulikud Eestis 19. sajandi algusest kuni 1944. Magistritöö. Tartu Ülikool, Eesti ajaloo õppetool.

A r n e k, Pille 2011. Eestikeelsed tekstid 19. sajandi Põhja-Eesti hauatähistel. Magistritöö. Tallinna Ülikool, Eesti Keele ja Kultuuri Instituut.

E i s e n, Matthias Johann 1921. Sugunimede tekkimine. - Eestlasele Eesti nimi. Tartu: Akadeemiline Emakeele Selts, lk 9-15.

K a s k, Arnold 1958. Võitlus vana ja uue kirjaviisi vahel XIX sajandi eesti kirjakeeles. Tallinn: Eesti Riiklik Kirjastus.

K o r b, Anu 2007. Rõžkovo virulased pärimuskultuuri kandjaina. Tartu: Eesti Kirjandusmuuseum.

Koli-ramat 1860 = Koli-ramat. Essimenne jaggo. Lühhikenne öppetus öigest kirjotamissest. Tartu: H. Laakmann.

M u s t, Aadu 2000. Eestlaste perekonnaloo allikad. Tartu: Kleio.

SAAGA = http//:www.ra.ee/dgs/explorer.php (Rahvusarhiivi ja Tallinna Linnaarhiivi digiteeritud arhiiviallikad).

S a a r e s t e, Andrus 1935. Eesti liignimedest varemalt, nüüd ja tulevikus. Tallinn: Nimede Eestistamise kesktoimkond.

T i i k, Leo 1969. Perekonnanimesid Hiiumaalt. - Keel ja Kirjandus, nr 9, lk 531534.

T i i k, Leo 1987. Perekonnanimede panekust Eestimaa talurahvale 1835. aastal. Keel ja Kirjandus, nr 2, lk 83-88. 


\section{Orthography of Estonian personal names on $19^{\text {th }}$-century grave markers and in church registers}

Keywords: personal names, epitaphs, Estonian language history

In $19^{\text {th }}$-century Estonia the local tradition of name spelling displayed considerable variance, even among well educated men of letters. Not all variations were accidental, though. The article compares the Estonian personal names inscribed on 19th-century grave markers with the respective entries in birth and death registers. The epitaphs enable a glimpse of the language usage of ordinary people. The church registers were completed by pastors, while the text on the gravestone was inscribed by a blacksmith or stonemason, sometimes an engraver or the peasant himself. This enables a comparison between the spelling traditions of pastors (or other learned men) versus those of craftsmen and peasants. The analysis addresses Estonian epitaphs from 18 cemeteries, which contain about 500 names. The reasons for inconsistent name spellings in the $19^{\text {th }}$ century are several and they often occur in combinations: the authority of landlords and pastors, the status of prestige of the German language, Estonian influences, the spelling reform, the persistence of old cognomens in parallel with recently received family names, etc. The authority of landlords was manifested just in the 1820s and 1830s, when they gave their peasants family names. The pastors' major influence, however, is reflected in first names as those were given in baptism. In addition, pastors were responsible for register entries. The landlords tended to prefer German-looking names. A comparison of epitaphs with church registers reveals cases where the pastor has been pro Estonianization whereas the peasant has preferred a more German-like name. But there are also reverse situations where the gravestone or cross bears a name spelt more Estonian-like than the one in the church register. Old cognomens, which have often been used on grave markers, even after the official campaign of giving family names, are less frequent in church registers. In many cases the headstone cross bears a short variant of the first name, frequently used as alias. A lot of differences are due to the spelling reform. In general, spelling variance was found to be higher on grave markers than in church registers. The effect of dialectal (and other regional) influences needs further research.

Pille Arnek (b. 1982), Tallinn University, doctoral student in linguistics, pille.arnek@gmail.com 